\title{
SIGNIFICANCE RISKS EVALUATION OF COMMERCIAL CONSTRUCTION PROJECTS
}

\begin{abstract}
J. KONIOR ${ }^{1}$
The main objective of the article is to present quantified and measurable risks likelihood appearance, impact and significance of inspected and monitored 48 commercial construction projects and their feasibility to be carried out. Original technical, financial and organisational feasibility studies in compliance with a rigorous Bank Investment Supervision requirements have been executed by the author in the period of $2005-2018$. Methodology of construction project appraisal for financing and execution professional preparation have been laid out - technical documentation, arrangements, realisation. Analysis and assessment of Bank Investment Supervision consisted of project execution plan PEP, geotechnical and environmental conditions, permit design, agreements and decision impacts of local authorities, engineering contract for construction works, project insurance and performance bonds, schedule of execution tasks and their costs, payment plan, investment budget and project economical effectiveness, scope of monthly construction works execution assessed by Earned Value Method approach and handover procedure of construction project. An attempt was made to express numerically the relationship between risks impacts and their level of likelihood. Also, a method of associating the influence of projects risks impacts on the extent of the likelihood of project risk occurrence which makes possible to determine the direction and the strength of this relationship was presented. Finally, risks likelihood appearance, impact and significance variability of commercial construction projects within last two years of booming investment industry have been determined.
\end{abstract}

Keywords: construction project, risk significance, correlation

\section{INTRODUCTION}

Project risk is defined as an unplanned event or condition that, if occurs, has a negative effect on a Project Objective. Risk management stands for identification, assessment, and prioritization of risks

\footnotetext{
${ }^{1}$ PhD., Eng., Wroclaw University of Science and Technology, Faculty of Civil Engineering, Department of Construction Technology and Management, Wybrzeże Wyspiańskiego 27, 50-370 Wrocław, Poland, e-mail: jaroslaw.konior@pwr.edu.pl
} 
defined in ISO 31000 followed by coordinated and economical allocation of resources to minimize, monitor, and control the probability and / or impact of unfortunate events or to maximize the realization of opportunities. Several risk management standards have been developed in construction management companies for years, enhanced by implementation ISO 9001 standard such as presented in works of Zavadskas, Turskisb, Tamošaitienec [21].

While estimating risks in construction projects, experts face problems of working on the qualitative (immeasurable data) basis rather than on a quantitative one. The decision making theory presents a classical split of such situations that have been presented from four following points of view [6], [7], [8], [10]:

- certainties: the entire information describing the decision making process is deterministic in character;

- risk: the entire information describing the decision making process is probabilistic;

- uncertainties: even the probability distributions are unknown;

- fuzzy state: uncertainties tackle not only the existence of an event appearance but its overall meaning that cannot be described by probabilistic methods [5], [6], [9].

\section{LITERATURE REVIEW}

Clearly laid out approach to construction risk identification, quantifying and measure has been presented by Zavadskas, Turskisb, Tamošaitienec [21] for whom the project risks can be divided into three groups: external, project, internal. Any risk management process in construction is extreme and important. Risk measure includes risk level determination of each objective and the risk analysis estimation by applying various approaches and technology. Risk control process evaluates performance of risk control. The authors were first who divided risk assessment according to object life cycle environment and allocated risk structure by level in construction object.

Similar approach to risk is applied by Almeida, Sousa, Dias, Branco but mostly referred to managing the risk of building structures performance in surrounding environment [1,2]. Also methods and models of measurable risk quantification in terms of the overall life cycle cost of buildings have been elaborated in several of papers by Plebankiewicz, Zima, and Wieczorek $[14,15,16]$.

Risks type and examples has been nicely divided by Szymański [19]. The most common risk division is classified in terms of occurrence frequency and the scope of impact. In general terms, the division is as follows: 
- risk in terms of frequency:

○ systematic risk, otherwise market risk independent of entity control;

○ specific risk relating to specific projects, along with all variants;

- risk in terms of impact scope:

○ fixed risk, concerning the whole economic system;

○ variable risk, otherwise non-fixed concerning a given enterprise.

Supplementary approach to the topic of risky projects were presented by Hanak, Korytarova [4] who investigated which risk causes arise from the financing of construction projects from public subsidy sources and whether certain risk sources can be considered as dominant if repeat with a higher frequency than the others.

Numerical method of quantitative identification and assessment of construction risks value has been presented in a pair of papers published by Kasprowicz [7, 8]. The author presented quantified risks models which contain basic probabilistic data for scheduling, cost estimating, assessment of the construction. The practical method of construction risk assessment allows contractors to examine changes of construction risk depending on conditions of construction and depending on different values of a project deadline and its capital cost.

Although the presented approach of projects risks assessment by linking risks impacts with their likelihood occurrence is quite well described in accessible literature and papers laid out by Mak, Picken [11], Silvestre, Silva, de Brito, Skorupka [17], Smith, Merna, Jobling [18], Szymański [19], Zavadskas, Turskisb, Tamošaitienec [21] but there is still insufficient number of construction projects reported and tested in measurable way. The data of enterprises in construction industry are under confidentiality agreements and well protected by global clients, project management companies and credit bank analysts. To make thing worse some of the projects risks may or may not occur, therefore their nature is moved to fuzzy sets categories [9] rather than belonging to probabilistic area where models of likelihood risks impacts may be determined easily.

\section{RESEARCH SAMPLE}

On the basis of the 13-year author's practice of Bank Investment Supervision developed methodology significant construction projects risks have been identified and measured: risks of the highest impact values and risks of the biggest likelihood appearance. The research has been recorded in 478 reports of 48 investment projects in advanced manufacturing, commercial, residential, hotels and apartment housing sectors:

- 2 industrial facilities - 14 reports; 
- 13 commercial and shopping centres -128 reports;

- 11 offices buildings - 116 reports;

- 15 apartment houses settlements -144 reports;

- 7 hotels -76 reports.

The Bank Investment Supervision (BIS) / Project Monitoring services stand for monitoring of a construction project in terms of quality as well as the financial schedule of works, in order to evaluate the progress of works in respect of the loan drawdown provisions.

BIS approach of monitoring, analysing and real inspections on construction sites throughout Poland is imposed by a financing banks carefully quantifying their financial credits on monthly basis presented by BIS in format of independent, audit reporting.

\section{SCOPE OF BIS}

Based on the scope of services outlined below, initial site inspection, interviews with the Investor's project management team and other project parties, analysis of the design and technical documentation for permit furnished by the Investor, the initial, monthly and final reports include the following:

- general characteristics of the project, data of the property, data on space and cubic capacity, architectural and construction description;

- confirmation that the borrower has obtained all permits, clearances, opinions, arrangements and decisions necessary to carry out the project;

- opinion regarding fulfilment by the Investor of all obligations and requirements resulting from the local spatial development plan, decision on development conditions, building permit and other documents;

- assessment of the contents of the technical project documentation which will be necessary to carry out the project;

- opinion concerning the construction contract and other agreements related to project execution, including verifying whether the project has been contracted and if the costs of the project contractor and payment conditions are consistent with market conditions; 
- assessment of the preliminary project budget and the project performance schedule: i.e. if the costs of construction works and additional works are at market levels and are sufficient to perform the scope of work, together with an assessment of the investment's economic feasibility in relation to the plan of costs and cash flows approved by the Investor;

- confirmation of project performance pursuant to the preliminary project performance schedule;

- opinion on the progress of construction and the quality of works up to the date of inspection and deviations from the contractual and project plans;

- opinion on the matter of significant entries to the construction log influencing the progress of works and pointing to possible threats that may influence the correct course of the investment process;

- confirmation of the scope of the project insurances, including confirmation that the project contractor, investor and other participants in the investment process have insurance agreements in effect providing appropriate insurance and civil liability protection for the investment;

- assessment of the organizational structure in place for the investment,;

- confirmation of equity investments made;

- confirmation that subcontractors payments are up to date;

- opinion, based on the conclusions made by the BIS during the site visit, on the current project progress including an assessment of physical progress of construction works and an assessment of the progress of works since the previous inspection as well as deviations of progress from the project schedule;

- analysis of significant entries to the construction log assessment of the project schedule performance and the project budget performance (review of cash flows);

- confirmation that the value of the performed construction works and additional costs meets the amount of cash funds invested in the project;

- opinion concerning the achievability of the project budget, in individual budget items;

- opinion on extra / additional construction works in terms of the project budget and schedule;

- assessment of invoices and other financial documents being the basis for the disbursement of the tranche of the loan or VAT loan, in their consistency with the construction contract, project Budget and other agreements;

- $\quad$ significant current issues and actions - especially information on delays and threats to investment performance; 
- opinion on investment completion and commissioning, including consistency of the completed project with the facility design, project budget and project schedule;

- opinion confirming the possibility for the Investor to obtain a final investment permit for use and opinion of the construction facility performance being consistent with the decision on development conditions, the construction project and conditions of the building permit;

- confirmation of completion of the works by the project contractor pursuant to the construction contract, removal of all defects and final takeover of the building by the Investor.

The research sample stands for 478 reports of 48 investment projects investigated, measured, reported and recorded in entirely set up construction and banking standards. Therefore the research sample is solid, consistent, reliable and definitely may be treated as typological probe for extrapolating the research results for entire population of construction enterprises recently carried out throughout in Poland.

\section{ASSOCIATION OF RISKS}

The status of the risks identified during the risk assessment inspections is vividly graphically shown on the risk $3 \mathrm{D}$ graph - figure 1 . The number of risks occurrence issues associated with their impacts and likelihood of appearance is combined altogether.

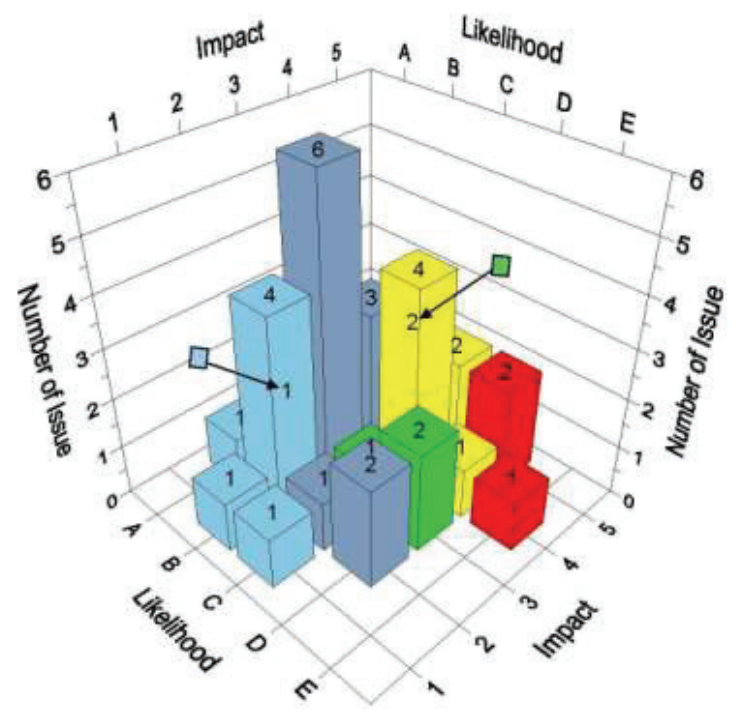

Fig. 1. Number of issues by impact and likelihood 
An assessment of the risk impact and its likelihood occurrence relies on identification of two types of variables [6], [7], [8]:

- non-measurable - qualitative variables, i.e. individual project risks impacts $i_{i j}$;

- measurable - quantitative variables, i.e. likelihood of individual project risks occurrence $\mathrm{l}_{\mathrm{i}}$.

After the types of variables $l i$ and $i_{i j}$ have been defined, an attempt was made at the numerical expression of relationship (should such relationships exist) between them, i.e. an attempt at measuring the influence of projects risks impacts on the extent of the likelihood of project risk occurrence. In the calculation of the strength of this relationship, the method of determination of the point bi-serial correlation coefficient (generally marked as $r(L)$ ) for the measurable property $l_{i}$ and the dichotomous property $\mathrm{i}_{\mathrm{ij}}$, was used. This is one of a few cases in the statistics when properties of various types are being correlated. The coefficient of correlation value falls within an interval [$1,1]$. In the sets of impacts I for each elementary impact $i_{i j}=i i($ when $j=1,2, \ldots, m)$ and the likelihood of project risks L, the following was determined [12]:

- $\mathrm{i}_{\mathrm{i}}$ - dichotomous variable that takes on values $0\left(\mathrm{i}_{\mathrm{i}} 0\right)$ or $1\left(\mathrm{i}_{\mathrm{i}} 1\right) ; \mathrm{i}=1,2, \ldots, \mathrm{n}$;

- $\mathrm{i} 0$ - number of observations of the variable $\mathrm{i}_{\mathrm{i}}$ marked as 0 ;

- $\mathrm{i} 1$ - number of observations of the variable $i_{i}$ marked as 1 ;

apparently $i=i_{0}+i_{1}$ (if by $i$, one shall understand the number of all observations $i_{i}$ ), and:

- $\mathrm{l}_{\mathrm{i}}$ - measurable variable; values of this variable were divided into two groups distinguished on this basis of: whether $1_{j}$ takes values 0 or $1 ; i=1,2, \ldots, n$;

- $1 \mathrm{i} 0$ - value of the property $\mathrm{l}_{\mathrm{i}}$ for these units ,i”, for which the property $\mathrm{i}_{\mathrm{i} 0}$ occurs;

- li1 - value of the property $l_{i}$ for these units ,i”, for which them property $i_{i 1}$ occurs. Next, arithmetic averages were calculated in the both groups:

$$
\begin{gathered}
\overline{l_{0}}=\frac{1}{i_{0}} \sum_{i=1}^{i_{0}} l_{i 0} \\
\overline{l_{1}}=\frac{1}{i_{1}} \sum_{i=1}^{i_{1}} l_{i 1}
\end{gathered}
$$

the standard deviation (determined for the correlation $\mathrm{r}(1)$ with a relationship defined the other way):

$$
d(L)=\sqrt{\frac{i \sum_{i=1}^{i} l_{i}^{2}-\left(\sum_{i=1}^{i} l_{i}\right)^{2}}{i(i-1)}}
$$

and as a result, on the basis of (1-3), the point bi-serial correlation coefficient $r(1)$ :

$$
r(l)=\frac{\overline{l_{1}}-\overline{l_{0}}}{d(L)} \sqrt{\frac{i_{1} i_{0}}{i(i-1)}}
$$


The above presented method of associating of the influence of projects risks impacts on the extent of the likelihood of project risk occurrence makes possible to determine the direction and the strength of this relationship shown in figure 1.

The point bi-serial correlation coefficients $\mathrm{r}(\mathrm{l})$ have been determined to measure reason-effect relationship 'risks impacts - likelihood of risks occurrence' on the basis of these projects analysis. As to test such preliminary associations only major 8 investment process risks have been selected to research and calculate if and how strong risks impacts $i_{i j}$ and risks likelihood $l_{i}$ correlate with each other in pairs. The results of $r(1)$ chosen coefficients have been presented in the table 1 .

Table 1. Point Bi-serial coefficients between project risks impacts and risks occurrence

\begin{tabular}{|c|c|c|c|c|c|c|}
\hline \multirow{2}{*}{ No } & \multirow{2}{*}{ Risks Occurred } & \multicolumn{5}{|c|}{$\mathrm{r}(\mathrm{l})$ for Risks Impacts by Categories } \\
\cline { 3 - 7 } & & Very Low & Low & Medium & High & Critical \\
\hline 1 & Scope & 0.18 & 0.21 & 0.29 & 0.32 & 0.34 \\
\hline 2 & Schedule & 0.26 & 0.29 & 0.39 & 0.58 & 0.71 \\
\hline 3 & Budget & 0.29 & 0.35 & 0.46 & 0.68 & 0.88 \\
\hline 4 & Quality & 0.16 & 0.20 & 0.26 & 0.31 & 0.35 \\
\hline 5 & Design & 0.28 & 0.31 & 0.42 & 0.52 & 0.73 \\
\hline 6 & Health \& Safety & 0.32 & 0.40 & 0.51 & 0.69 & 0.95 \\
\hline 7 & Environmental & 0.15 & 0.19 & 0.22 & 0.31 & 0.33 \\
\hline 8 & Handover & 0.20 & 0.23 & 0.32 & 0.39 & 0.46 \\
\hline
\end{tabular}

This is the simplest method for associating the influence of projects risks impacts on the extent of the likelihood of project risk occurrence which makes possible to determine the direction and the strength of this relationship.

\section{BANK INVESTMENT SUPERVISION RISKS}

Entire group of appeared and pinpointed risks in 478 reports of 48 investment projects has been divided into 3 groups equivalent to 3 phases of investment process:

- $\mathrm{P}$ - phase of projects preparation and design works

- C - phase of projects construction and erection

- $\mathrm{M}$ - phase of projects maintenance and exploitation

for which the most significant risks have been determined [4-7] and presented in the tables 2, 3 and 4 . 
Table 2. Risks significance - phase $\mathrm{P}$ of projects preparation and design works

\begin{tabular}{|c|l|c|c|c|}
\hline No & \multicolumn{1}{|c|}{$\begin{array}{c}\text { Significant risks at preparation and design works - } \\
\text { phase P }\end{array}$} & $\begin{array}{c}\text { Impact } \\
{[0 ; 1]}\end{array}$ & $\begin{array}{c}\text { Likelihood } \\
{[0 ; 1]}\end{array}$ & $\begin{array}{c}\text { Significance } \\
{[0 ; 1]}\end{array}$ \\
\hline 1 & Delayed agreements and environmental decisions & 1.00 & 0.30 & 0.30 \\
\hline 2 & $\begin{array}{l}\text { Building Permit Design non-compliant with and Act } \\
\text { of Building Permit Design Scope and Form }\end{array}$ & 1.00 & 0.10 & 0.10 \\
\hline 3 & Protest against Building Permit & 1.00 & 0.10 & 0.10 \\
\hline 4 & Unconfirmed Investor's Own Equity & 1.00 & 0.20 & 0.20 \\
\hline 5 & Inconsistent administrative building decisions & 0.50 & 0.40 & 0.20 \\
\hline 6 & Irrational procurement process for construction works & 0.20 & 0.10 & 0.02 \\
\hline 7 & Incorrect structured budget for construction works & 0.70 & 0.20 & 0.14 \\
\hline 8 & Unappropriated level of budget contingency & 0.30 & 0.40 & 0.12 \\
\hline 9 & Improperly calculated break-even point of the project & 0.50 & 0.10 & 0.05 \\
\hline 10 & $\begin{array}{l}\text { Unbalance parameters of Cost - Time - Quality } \\
\text { within agreement for construction works }\end{array}$ & 0.60 & 0.20 & 0.12 \\
\hline
\end{tabular}

Table 3. Risks significance - phase $\mathrm{C}$ of construction and erection

\begin{tabular}{|c|l|c|c|c|}
\hline No & \multicolumn{1}{|l|}{$\begin{array}{c}\text { Significant risks at construction and erection - phase } \\
\text { C }\end{array}$} & $\begin{array}{c}\text { Impact } \\
{[0 ; 1]}\end{array}$ & $\begin{array}{c}\text { Likelihood } \\
{[0 ; 1]}\end{array}$ & $\begin{array}{c}\text { Significance } \\
{[0 ; 1]}\end{array}$ \\
\hline 1 & Contractors not mobilised for construction works & 0.70 & 0.20 & 0.14 \\
\hline 2 & Not following Health \& Safety requirements on site & 0.90 & 0.30 & 0.27 \\
\hline 3 & $\begin{array}{l}\text { Delays of construction works in comparison to their } \\
\text { schedule }\end{array}$ & 0.60 & 0.40 & 0.24 \\
\hline 4 & $\begin{array}{l}\text { Deviation of project budget use in comparison to } \\
\text { financial plan }\end{array}$ & 0.50 & 0.30 & 0.15 \\
\hline 5 & $\begin{array}{l}\text { Undisciplined management of additional and } \\
\text { substitute construction works }\end{array}$ & 0.90 & 0.10 & 0.09 \\
\hline 6 & $\begin{array}{l}\text { Insufficient supervision of quality and compliance of } \\
\text { construction works }\end{array}$ & 0.80 & 0.30 & 0.24 \\
\hline 7 & $\begin{array}{l}\text { Inadequate Design Author Supervision and } \\
\text { classification of significant changes of design } \\
\text { solutions }\end{array}$ & 0.70 & 0.10 & 0.07 \\
\hline 8 & $\begin{array}{l}\text { Overstating of monthly quantities of construction } \\
\text { works performed }\end{array}$ & 0.50 & 0.30 & 0.15 \\
\hline 9 & $\begin{array}{l}\text { Insufficient preparation for a building handover by } \\
\text { Fire, Sanitary and Technical Supervision Authorities }\end{array}$ & 0.70 & 0.20 & 0.14 \\
\hline 10 & $\begin{array}{l}\text { Not obtaining Operation Permit issued by } \\
\text { Construction Supervision Authority }\end{array}$ & 0.90 & 0.10 & 0.09 \\
\hline
\end{tabular}

Table 4. Risks significance - phase $\mathrm{M}$ of maintenance and exploitation

\begin{tabular}{|c|c|c|c|c|}
\hline No & $\begin{array}{c}\text { Significant risks at maintenance and exploitation - } \\
\text { phase } \mathrm{M}\end{array}$ & $\begin{array}{c}\text { Impact } \\
{[0 ; 1]}\end{array}$ & $\begin{array}{l}\text { Likelihood } \\
{[0 ; 1]}\end{array}$ & $\begin{array}{c}\text { Significance } \\
{[0 ; 1]}\end{array}$ \\
\hline 1 & $\begin{array}{l}\text { Insufficient commercialisation or production capacity } \\
\text { of commercial investment }\end{array}$ & 1.00 & 0.30 & 0.30 \\
\hline 2 & $\begin{array}{l}\text { Long lasting payback period with delay of break- } \\
\text { even point }\end{array}$ & 1.00 & 0.20 & 0.20 \\
\hline 3 & $\begin{array}{l}\text { Post guarantee handover with many defects for } \\
\text { removal or fee reduction }\end{array}$ & 0.80 & 0.20 & 0.16 \\
\hline
\end{tabular}




\begin{tabular}{|c|l|c|c|c|}
\hline 4 & $\begin{array}{l}\text { Retaining of fee in cash or performance bond as a } \\
\text { due to poor quality of construction works after } \\
\text { ineffective post guarantee handover }\end{array}$ & 0.80 & 0.20 & 0.16 \\
\hline 5 & $\begin{array}{l}\text { Inappropriate building exploitation not compliant } \\
\text { with a building maintenance book }\end{array}$ & 0.20 & 0.10 & 0.02 \\
\hline
\end{tabular}

Certainly, investigated within last 13 years investment project risks' impacts, likelihood and significance are not constant values but variables ones which are prone to change in line with a global and Polish construction market changes. Trend and variability of the most vivid and deviated values of significance in a period of the last 2 years have been presented in the table 5 .

Table 5. Risks significance deviation in last 2 years - phases P, C, M

\begin{tabular}{|c|l|c|c|c|}
\hline \multirow{2}{*}{ No } & \multicolumn{1}{|c|}{ Deviation of significant risks } & \multicolumn{2}{c|}{ Significance $[0 ; 1]$} & $\begin{array}{c}\text { Significance } \\
{[0 ; 1]}\end{array}$ \\
\cline { 3 - 5 } & & $2005-2016$ & $\begin{array}{c}2016- \\
2018\end{array}$ & Change [0;1] \\
\hline 1 & Protest against Building Permit & 0,10 & 0,25 & +0.15 \\
\hline 2 & Not following Health \& Safety requirements on site & 0,27 & 0,13 & -0.14 \\
\hline 3 & $\begin{array}{l}\text { Delays of construction works in comparison to their } \\
\text { schedule }\end{array}$ & 0,24 & 0,31 & +0.07 \\
\hline 4 & $\begin{array}{l}\text { Deviation of project budget use in comparison to } \\
\text { financial plan }\end{array}$ & 0,15 & 0,31 & +0.16 \\
\hline 5 & $\begin{array}{l}\text { Undisciplined management of additional and } \\
\text { substitute construction works }\end{array}$ & 0,09 & 0,19 & +0.10 \\
\hline 6 & $\begin{array}{l}\text { Insufficient supervision of quality and compliance of } \\
\text { construction works }\end{array}$ & 0,24 & 0,13 & -0.11 \\
\hline 7 & $\begin{array}{l}\text { Overstating of monthly quantities of construction } \\
\text { works performed }\end{array}$ & 0,15 & 0,06 & -0.09 \\
\hline 8 & $\begin{array}{l}\text { Insufficient preparation for a building handover by } \\
\text { Fire, Sanitary and Technical Supervision Authorities }\end{array}$ & 0,14 & 0,06 & -0.08 \\
\hline
\end{tabular}

\section{CONCLUSIONS}

\subsection{RISKS IMPACTS - LIKELIHOOD CORRELATION}

The point bi-serial correlation coefficients $\mathrm{r}(\mathrm{l})$ have been determined for indicative research and indicate the following conclusions:

- the direction of the relationship is right-hand (positive) for all 8 risks assessed and occurred but the strength of correlation between project risks impacts and likelihood of project risks occurrence shows a considerable span (from 0.18 to 0.95 ); 
- the unanimous trend of bi-serial correlation coefficients $r(1)$ growth has been observed - the higher / more serious project risk impact, the bigger value of $r(1)$ is;

- the trend of $\mathrm{r}(\mathrm{l})$ is more significant and the values of coefficients are exceeding 0.5 for projects risks which are more measurable and easier to quantify then others: project schedule, cost budget, design technical issues and safety constrains.

\subsection{RISKS IMPACTS - LIKELIHOOD SIGNIFICANCE}

All identified risks appearing at entire life - cycle of construction projects have been presented in tables 1, 2 and 3. At least one risk [8-10] of the highest measured level of significance (around 0.3) is highlighted at each phase of investment process:

- Phase P: Delayed agreements and environmental decisions;

- Phase C: Not following Health \& Safety requirements on site;

- Phase M: Insufficient commercialisation or production capacity of commercial investment.

There are further conclusions drawn from deeper analysis of 450 - 500 BSI reports elaborated on 48 construction projects:

- Identified above risks of investment process have a significant impact (on average 0.65) on success of a construction project;

- Majority of construction risks appear with likelihood not exceeding the value 0.4.;

- Risks of the highest impact values affect the monitored projects with pretty low level of likelihood and those of the lowest impact values are aligned with higher level of likelihood. Lack of correlation of risks impact and their likelihood at really high level determines reasonable level of risks significance, not higher than $1 / 3$ of possible significance in "risks monitoring" strategy. Therefore, all professionally monitored construction risks are "manageable";

- Engineering, Project and Construction Management (EPCM) approach to investment process and solid, consequent, regular construction projects monitoring executed by professional Banking Supervision Inspector, make possible to minimise any faults of inappropriate financing of construction projects;

- Trend and variability of the most vivid and deviated values of significance in a period of the last 2 years have been determined and varies for 8 measured risks out of 25 overall pinpointed ones. Standard deviation of risks significance is within the range of change +0.16 $/-0.11$ in scale of $[-1 ;+1]$. 


\section{SUMMING UP}

Original technical, financial and organisational feasibility studies in compliance with a rigorous Bank Investment Supervision requirements have been executed by the author in the period of 2006 - 2018. Methodology of construction project appraisal for financing and execution professional preparation have been laid out - technical documentation, arrangements, realisation.

The main value of the paper is a research sample that stands for $450-500$ reports of 48 investment projects investigated, measured, reported and recorded in entirely set up construction and banking standards

As a result of the research quantified and measurable risks likelihood appearance, impact and significance of inspected and monitored 48 commercial construction projects have been determined. An attempt was made to express numerically the relationship between risks impacts and their level of likelihood. Also, a method of associating the influence of projects risks impacts on the extent of the likelihood of project risk occurrence which makes possible to determine the direction and the strength of this relationship was presented. Finally, risks likelihood appearance, impact and significance variability of commercial construction projects within last two years of booming investment industry have been assessed.

The research results are original and the research sample is solid, consistent, reliable and definitely may be treated as typological probe for extrapolating the research results for entire population of construction enterprises recently carried out throughout in Poland. However, the approach, the research and the conclusions presented in the article - even indicative ones - are worth further investigations and exploring. This will make more possible pinpoint, determine, monitor and mitigate the most impactful risk appearing in construction projects. 


\section{REFERENCES}

[1] N.M. Almeida, V. Sousa, L. A. Dias, F. Branco, "Engineering risk management in performance-based building environments", Journal of Civil Engineering and Management, 2015, pp. 218-230.

[2] N.M. Almeida, V. Sousa, L. A. Dias, F. Branco, "Managing the technical risk of performance-based building structures", Journal of Civil Engineering and Management, 2015, pp. 384-394.

[3] S. Chi, S. Han, D.Y. Kim, Y. Shin, "Accident risk identification and its impact analyses for strategic construction safety management", Journal of Civil Engineering and Management, 2015, pp. 524-538.

[4] T. Hanak, J. Korytarova, "Subsidy risk related to construction projects: seeking causes", Open Engineering, 2018, pp. 484-489.

[5] N. Ibadov, J. Kulejewski, "The assessment of construction project risks with the use of fuzzy sets theory", Technical Transactions, 2014, pp. 175-182.

[6] O. Kapliński, J. Konior, "Analytical methods and models in the building project engineering”, PAN, 2007, pp. 249284.

[7] T. Kasprowicz, "Quantitative identification of construction risk", Archives of Civil Engineering, 2017, vol. LXIII, pp. 63-74.

[8] T. Kasprowicz, "Quantitative assessment of construction risk", Archives of Civil Engineering, 2017, vol. LXIII, pp. $55-66$.

[9] J. Konior, "Random and Fuzzy Measure of Unpredictable Construction Works", Archives of Civil Engineering, 2015, vol. LXI, pp. 75-87.

[10] J. Konior, "Enterprises Risk Assessment of Complex Construction Projects", Archives of Civil Engineering, 2015, vol. LXI, pp. 63-74.

[11] S. Mak, D. Picken, "Using risk analysis to determine construction project contingencies", Journal of Construction Engineering and Management, 2000, pp. 130-136.

[12] D.F. Morrison, "Multivariate statistical methods", McGraw - Hill Book Company, New York 1990, pp. 121-123.

[13] J.D. Silvestre, A. Silva, J. de Brito, "Uncertainty modelling of service life and environmental performance to reduce risk in building design decisions", Journal of Civil Engineering and Management, 2015, pp. 308-32.

[14] E. Plebankiewicz, K. Zima, D. Wieczorek, „Life cycle cost modelling of buildings with consideration of the risk", Archives of Civil Engineering, 2016, vol. LXII, pp. 149-166.

[15] E. Plebankiewicz, K. Zima, D. Wieczorek, "Quantification of the risk addition in life cycle cost of a building object”, Technical Transactions, 2017, vol. V, pp. 35-45.

[16] E. Plebankiewicz, K. Zima, D. Wieczorek, 2019. "Model Estimation of the Whole Life Cost of a Building with respect to Risk Factors", Technological and Economic Development of Economy, vol. XXV, pp. 20-38.

[17] D. Skorupka, "Identification and initial risk assessment of construction projects in Poland", Journal of Management in Engineering, 2008, pp. 120-127.

[18] N.J. Smith, T. Merna, P. Jobling, "Managing risk in construction projects", Wiley-Blackwell, 2009, pp. 16-19.

[19] P. Szymański, "Risk management in construction projects", Procedia Engineering, 2017, pp. 174-182.

[20] J. Yu, M. Jeon, T.W. Kim, "Fuzzy-based composite indicator development methodology for evaluating overall project performance", Journal of Civil Engineering and Management 2015, pp. 343-355.

[21] E.K. Zavadskas, Z. Turskisb, J. Tamošaitienec, "Risk assessment of construction projects", Journal of Civil Engineering and Management, 2010, pp. 33-46.

\section{LIST OF FIGURES AND TABLES:}

Fig. 1. Number of issues by impact and likelihood

Rys. 1. Wielkość Istotności w funkcji wpływu i prawdopodobieństwa

Tab. 1. Point Bi-serial coefficients between project risks impacts and risks occurrence

Tab. 1. Punktowe, dwuszeregowe współczynniki korelacji pomiędzy wpływem ryzyk a prawdopodobieństwem ich wystąpienia

Tab. 2. Risks significance - phase $P$ of projects preparation and design works

Tab. 2. Istotność ryzyk - faza P, przygotowanie i projektowanie

Tab. 3. Risks significance - phase $\mathrm{C}$ of construction and erection

Tab. 3. Istotność ryzyk - faza $\mathrm{C}$, budowa i realizacja

Tab. 4. Risks significance - phase $\mathrm{M}$ of maintenance and exploitation

Tab. 4. Istotność ryzyk - faza M, utrzymanie i użytkowanie

Tab. 5. Risks significance deviation in last 2 years - phases P, C, M

Tab. 5. Zmienność istotności ryzyk w ostatnich dwóch latach - fazy P, C, M 


\title{
POMIAR ISTOTNOŚCI RYZYK NIEPUBLICZNYCH PRZESIĘWZIĘĆ BUDOWLANYCH
}

\author{
Slowa kluczowe: przedsięwzięcie budowlane, istotność ryzyka, korelacja
}

\section{STRESZCZENIE}

W artykule przedstawiono techniczne, finansowe i organizacyjne metody oceny istotności ryzyk przedsięwzięć budowlanych podejściem i wymaganiami Nadzoru Bankowego. Zaprezentowano metodykę oceny poprawności przygotowania inwestycji niepublicznych do wykonania i finansowania oraz monitorowania ich realizacji według przyjętych, sparametryzowanych założeń kosztowych i czasowych. Celem badań była zestandaryzowana, mierzalna ocena kluczowych parametrów ryzyk zadań inwestycyjnych - ich wpływu, prawdopodobieństwa występowania $\mathrm{i}$ istotności - prowadząca do minimalizacji niewłaściwego kredytowania zadań inwestycyjnych przez Bank Finansujący. Analizie i ocenie poddano Plan Realizacji Projektu PRP, warunki geotechniczne i środowiskowe, projekt budowlany, uzgodnienia i decyzje administracyjne, kontrakt inżynierski, ubezpieczenia i gwarancje, harmonogram rzeczowo finansowy, plan płatności, budżet inwestycji i jej rentowność z okresem zwrotu, poziom miesięcznego przerobu robót budowlanych Metodą Wartości Wypracowanej EVM, pomiar istotnych ryzyk inwestycyjnych oraz procedurę odbiorową przedsięwzięcia budowlanego.

\section{METODYKA I PRZEBIEG BADAŃ}

Oryginalne dane do badań zebrano i przetworzono na podstawie ponad 30-letniego doświadczenia w zarządzaniu przedsięwzięciami budowlanymi i 13-letniego doświadczenia autora w prowadzeniu usług Nadzoru Bankowego, udokumentowanego w 478 raportach, na 48 zadaniach inwestycyjnych, w sektorze przemysłowym, biurowym, hotelowym i budownictwa mieszkaniowego.

W tak określonej, typologicznej próbie badawczej wyszczególniono ryzyka procesu inwestycyjnego:

- największym wpływie

- największym prawdopodobieństwie występowania

dla których wyróżniono ryzyka procesu inwestycyjnego o najwyższym zmierzonym poziomie istotności (0.3) w każdej fazie procesu inwestycyjnego w budownictwie - tab. 2, 3, 4:

- Przygotowania, Projektowania i Przetargu: Opóźnione uzgodnienia i decyzje środowiskowe;

- Realizacji: Nieprzestrzeganie zasad BHP na budowie;

- Utrzymania i Użytkowania: Niedostateczna komercjalizacja / zdolność produkcyjna inwestycji budowlanej. Zbadano również trend i zmienność 8 ryzyk inwestycyjnych, które występowały najczęściej w monitorowanych przedsięwzięciach budowalnych w okresie ostatnich dwóch lat - tab. 5 .

Korelację wpływu ryzyka na parametry wykonalności zadań inwestycyjnych z prawdopodobieństwem ich tych ryzyk wyznaczono w mierzalny sposób punktowym, dwuszeregowym współczynnikiem korelacji cech różnego rodzaju r(l):

$$
r(l)=\frac{\bar{l}_{1}-\bar{l}_{0}}{d(L)} \sqrt{\frac{i_{1} i_{0}}{i(i-1)}}
$$

Stwarza on możliwość skojarzenia wpływu ryzyka inwestycyjnego z prawdopodobieństwem jego występowania, jak również określenia kierunku i siły tego związku - tab. 1.

\section{WNIOSKI}

Zidentyfikowane powyżej ryzyka procesu inwestycyjnego mają znaczący wpływ (średnio 0.65) na powodzenie przedsięwzięcia budowlanego:

- $\quad$ większość ryzyk występuje z prawdopodobieństwem nie przekraczającym 0.4 ;

- ryzyka o największym wpływie występują z niewielkim prawdopodobieństwem, a te o najmniejszym wpływie z prawdopodobieństwem większym. Taki korzystny brak korelacji obu tych parametrów wskazuje na umiarkowany poziom istotności ryzyk procesu inwestycyjnego, nie przekraczający 1/3 możliwej istotności w strategii „monitorowania ryzyka”;

- ryzyka te są zatem „zarządzalne”, a rzetelny monitoring Nadzoru Bankowego umożliwia minimalizację błędu niewłaściwego finasowania zadań inwestycyjnych.

- trend i zmienność 8 z badanych 25 ryzyk inwestycyjnych, występujących z największym prawdopodobieństwem w monitorowanych przedsięwzięciach budowalnych w ostatnich dwóch latach została określona znakami $+/$ - i przedziałem odchylenia $+0.16 /-0.11$ w skali $[-1 ;+1]$. 
Wyniki badania tego związku punktowym, dwuszeregowym współczynnikiem korelacji cech różnego rodzaju r(l) prowadzą do następujących wniosków:

- $\quad$ kierunek związku jest prawostronny (dodatni) dla wszystkich 8 badanych ryzyk budowlanych, ale siła korelacji pomiędzy występującym wpływem ryzyka, a prawdopodobieństwem jego wystąpienia wykazuje znaczną rozpiętość (od 0,18 do 0,95 );

- zaobserwowano jednoznaczny trend zmiany współczynnika korelacji r(l) dla wszystkich 8 badanych obszarów ryzyk - im większy wpływ ryzyka inwestycyjnego tym większe prawdopodobieństwo jego wystąpienia;

- trend współczynnika r(l) jest szczególnie wyraźny i znaczący kiedy przekracza wartości 0.5 , co ma miejsce w przypadku łatwiej mierzalnych I kwantyfikowalnych obszarów ryzyk w przedsięwzięciu budowlanych: harmonogram inwestycji, budżet zadania, projektowanie techniczne i względy BHP.

\section{Podsumowanie}

Pomimo faktu, że metody oceny istotności ryzyk inwestycyjnych i badania ich asocjacji punktowym, dwuszeregowym współczynnikiem korelacji cech różnego rodzaju są szeroko opisane w dostępnej literaturze to ich aplikacja w modelowaniu przedsięwzięć budowlanych jest utrudniona $\mathrm{z}$ uwagi na niedoskonałość ich opisu parametrami mierzalnymi. Ponadto dane liczbowe zrealizowanych zadań inwestycyjnych są szczególnie chronione przez inwestorów korporacyjnych, firmy menedżerskie i departamenty kontroli ryzyka banków kredytowych. Trzeba również pamiętać, że nie ma pewności co do wystąpienia niektórych obszarów ryzyk budowlanych, a zatem ich natura leży bliżej rozmytości niż probabilistyki, z lepiej rozwiniętym aparatem matematycznym do modelowania procesów inwestycyjnych. Jednakże, podejście i wnioski zaprezentowane w artykule powinny skłaniać do prowadzenia dalszych badań, nawet $\mathrm{w}$ niedoskonałych próbach badawczych. Identyfikacja ryzyka budowlanego w przedsięwzięciach budowlanych, wyznaczenie siły jego wpływu, możliwości wystąpienia i istotności oraz jego monitorowanie i eliminowanie działaniami zapobiegawczymi są nie do przecenienia w prawidłowym zarządzaniu procesem inwestycyjnym w budownictwie.

Received 22.02.2019

Revised 30.06.2019 